\title{
Exposure to ergot alkaloids during gestation reduces fetal growth in sheep
}

\author{
Susan K. Duckett ${ }^{1 *}$, John G. Andrae ${ }^{2}$ and Scott L. Pratt ${ }^{1}$ \\ ${ }^{1}$ Animal and Veterinary Sciences Department, Clemson University, Clemson, SC, USA \\ ${ }^{2}$ School of Agricultural Forest and Environmental Sciences, Clemson University, Clemson, SC, USA
}

\author{
Edited by: \\ James Levi Klotz, United States \\ Department of Agriculture - \\ Agricultural Research Service, USA \\ Reviewed by: \\ Christian W. Gruber, Medical \\ University of Vienna, Austria \\ Alexander Shekhtman, University at \\ Albany, State University of New \\ York, USA \\ Lester Ronald Fletcher, AgResearch \\ NZ, New Zealand \\ *Correspondence: \\ Susan K. Duckett, Animal and \\ Veterinary Sciences Department, \\ Clemson University, 145 Poole Ag. \\ Center, Clemson, SC, USA \\ e-mail: sducket@clemson.edu
}

Tall fescue [Lolium arundinaceum (Schreb.) Darbysh; Schedonorus phoenix (Scop.) Holub] is the primary cool season perennial grass in the eastern U.S. Most tall fescue contains an endophyte (Neotyphodium coenophialum), which produces ergot alkaloids that cause vasoconstriction and could restrict blood flow to the fetus in pregnant animals. The objective of this study was to examine fetal growth during maternal exposure to ergot alkaloids during gestation. Pregnant ewes $(n=16)$ were randomly assigned to one of two dietary treatments: (1) endophyte-infected $(N$. coenophialum) tall fescue seed (E+; $0.8 \mathrm{ug}$ of ergovaline /g diet DM) and (2) endophyte-free tall fescue seed ( $\mathrm{E}-; 0.0 \mathrm{ug}$ of ergovaline/g diet DM). Birth weight of lambs was reduced by $37 \%$ for $\mathrm{E}+$ compared to $\mathrm{E}-$. Organ and muscle weights were also lighter for $\mathrm{E}+$ than $\mathrm{E}-$. Exposure to ergot alkaloids in utero reduces fetal growth and muscle development.

Keywords: sheep, ergot alkaloids, fetal growth, muscle development

\section{INTRODUCTION}

Tall fescue [Lolium arundinaceum (Schreb.) Darbysh; Schedonorus phoenix (Scop.) Holub] is the primary cool season perennial grass utilized in the eastern U.S. occupying more than 14 million ha (Stuedemann and Hoveland, 1988). The majority of tall fescue contains an endophyte (Neotyphodium coenophialum), which produces ergot alkaloids (i.e., ergovaline, ergovalinine, lysergic acid etc.). The endophyte is beneficial to the plant and improves establishment, persistence, and drought tolerance (Stuedemann and Hoveland, 1988); however, ingestion of the ergot alkaloids by grazing livestock results in fescue toxicosis which reduces animal growth (Hoveland, 1993) and reproductive performance (Peters et al., 1992). Ergot alkaloids contain a tetracyclic ergoline ring and are structurally similar to biogenic amines, serotonin, dopamine, norepinephrine, and epinephrine (Berde, 1980; Weber, 1980; Strickland et al., 2011). Ergot alkaloids bind to receptors for the biogenic amines and elicit decreased serum prolactin concentrations and vasoconstriction (Klotz et al., 2006, 2012; Aiken et al., 2009). Dyer (1993) found that ergovaline induced contraction of bovine uterine and umbilical cord arteries via $5 \mathrm{HT}_{2 \mathrm{~A}}$ serotonergic receptors, which could restrict blood flow to the fetus. Gestating ewes in the Southeastern US would generally be exposed to endophyteinfected tall fescue throughout the gestation period. Little research exists on how ergot alkaloid exposure in gestating ewes impacts fetal growth and development. The objective of this study was to assess how exposure to ergot alkaloids during gestation (d 35 to parturition) of ewes altered fetal growth and development.

\section{MATERIALS AND METHODS}

All animal experimental procedures were reviewed and approved by the Clemson University Institutional Animal Care and Use Committee (AUP-2011-053).

Southdown ewes $(n=20 ; \mathrm{BW}=70 \mathrm{~kg} ; \mathrm{BCS}=4)$ were mated to a single ram that was fitted with a marking harness. Ewes were checked twice daily and crayon marks from the ram's harness were denoted to estimate breeding date. Ewes were confirmed pregnant via transrectal ultrasonography on $\mathrm{d}$ 35 of gestation. Ewes confirmed pregnant $(n=16)$ were randomly assigned to one of two dietary treatments: (1) endophyteinfected ( $N$. coenophialum) tall fescue seed $(\mathrm{E}+; 0.8 \mu \mathrm{g}$ of ergovaline + ergovalinine/g diet DM) and (2) endophyte-free tall fescue seed (E-; $0.0 \mu \mathrm{g}$ of ergovaline + ergovalinine/g diet DM). Endophyte-infected and endophyte-free tall fescue seed (E+cv. Defiance, and E-cv. Fawn, turf-type tall fescue seed, Seed Research of Oregon, Tangent, OR) was first analyzed for ergovaline and ergovalinine levels according to Aiken et al. (2009) and then diets formulated to provide the targeted levels of ergovaline/ergovalinine in the diet. Fescue seed was delivered daily in a total mixed ration (Table 1) formulated to meet NRC requirements for pregnant ewes from d 35 to parturition.

Blood samples were collected from the ewes via jugular venipuncture into tubes on d 30, 50, and 130 of gestation. Samples were allowed to clot for $30 \mathrm{~min}$ at room temperature and then at $4^{\circ} \mathrm{C}$ overnight. Serum was obtained by centrifuging at $1000 \times g$ for $15 \mathrm{~min}$ at $4^{\circ} \mathrm{C}$ and stored frozen at $-20^{\circ} \mathrm{C}$. Prolactin (PRL) concentrations were measured using RIA according to the procedures of Bernard et al. (1993). 
Table 1 | Composition of the total mixed ration containing endophyte-infected tall fescue seed fed to the ewes during gestation.

\begin{tabular}{lc}
\hline Ingredient & \% of ration, DM \\
\hline Tall fescue seed & 38.5 \\
Cottonseed hulls & 15.4 \\
Molasses & 8.6 \\
Corn grain, cracked & 18.9 \\
Soybean hulls & 11.4 \\
Limestone & 0.2 \\
Soybean meal & 2.8 \\
NUTRIENT COMPOSITION, DM BASIS & \\
Crude protein & $11 \%$ \\
TDN & $60 \%$ \\
\hline
\end{tabular}

At parturition, a male lamb $(\mathrm{E}+=8 ; \mathrm{E}-=8)$ was removed from each ewe carrying twins. If two male lambs were born to the same ewe, the firstborn male lamb was removed from the dam. Male lambs were given a fixed amount of artificial colostrum (Lamb's Choice Total, The Saskatoon Colostrum Co., 3 oz. reconstituted dried bovine colostrum) and harvested within $12 \mathrm{~h}$ of birth. The attending veterinarian euthanized lambs with an overdose of pentobarbital. Live weight was collected for each lamb and then the lamb was exsanguinated. The hide, head, feet, and tail were removed and weight of the carcass obtained. Weights were collected on all organs and total digestive tract. From the left side of each carcass, individual muscles [longissimus thoracis (LT), gluteus medius, semimembranosus, semitendinosus, biceps femoris, and quadriceps femoris] were collected and weighed. Samples of the longissimus and semitendinosus muscles were immersed in optimal cutting temperature solution, frozen in liquid nitrogen, and stored at $-80^{\circ} \mathrm{C}$. for subsequent fiber typing. Adipose depots (subcutaneous fat, kidney fat, mesenteric fat) were also collected and weighed. No appreciable subcutaneous fat depots were present in any of the lambs. From the right side of each carcass, all muscle and fat were removed, weighed and ground for total body proximate composition.

\section{PROXIMATE COMPOSITION}

For proximate analysis, total muscle and fat samples from the right side of each lamb carcass were chopped (Blixer ${ }^{\circledR 3}$ Series D, Robot Coupe Inc., Ridgeland, MS) to reduce particle size and subset removed for determination of moisture content. The remaining samples were frozen at $-20^{\circ} \mathrm{C}$, lyophilized (VirTis, SP Scientific, Warminster, PA), ground (Blixer ${ }^{\circledR} 3$ ), and stored at $-20^{\circ} \mathrm{C}$. Duplicate samples were analyzed for nitrogen content by the combustion method using a Leco FP-2000 N analyzer (Leco Corp., St. Joseph, MI) and multiplied by 6.25 to determine $\mathrm{CP}$ content. Moisture content was determined by weight loss after drying at $100^{\circ} \mathrm{C}$ for $24 \mathrm{~h}$. Total ash content was determined by ashing at $600^{\circ} \mathrm{C}$ for $8 \mathrm{~h}$. Total fat content was determined in duplicate using Ankom XT-15 Extractor (Ankom Technology, Macedon, NY) and hexane as solvent.

\section{FATTY ACID COMPOSITION}

Freeze dried total muscle and fat samples from the right side of each lamb carcass were transmethylated according to the method of Park and Goins (1994). Fatty acid methyl esters (FAME) were analyzed using an Agilent 6850 (Agilent, San Fernando, CA) gas chromatograph equipped with an Agilent 7673A (HewlettPackard, San Fernando, CA) automatic sampler. Separations were accomplished using a 100-m SP2560 (Supelco, Bellefonte, PA) capillary column $(0.25 \mathrm{~mm}$ i.d. and $0.20 \mu \mathrm{m}$ film thickness). Column oven temperature increased from 150 to $160^{\circ} \mathrm{C}$ at $1^{\circ} \mathrm{C}$ per min, from 160 to $167^{\circ} \mathrm{C}$ at $0.2^{\circ} \mathrm{C}$ per min, from 167 to $225^{\circ} \mathrm{C}$ at $1.5^{\circ} \mathrm{C}$ per $\mathrm{min}$, and then held at $225^{\circ} \mathrm{C}$ for $16 \mathrm{~min}$. The injector and detector were maintained at $250^{\circ} \mathrm{C}$. Sample injection volume was $1 \mu \mathrm{L}$. Hydrogen was the carrier gas at a flow rate of $1 \mathrm{~mL}$ per min. Samples were run twice with a split ratio of 100:1 for trans C18:1 and long-chain fatty acids, and again at split ratio of 10:1 for conjugated linoleic acid (CLA) and omega-3 fatty acids. Individual fatty acids were identified by comparison of retention times with standards (Sigma, St. Louis, MO; Supelco, Bellefonte, PA; Matreya, Pleasant Gap, PA). Fatty acids were quantified by incorporating an internal standard, methyl tricosanoic (C23:0) acid, into each sample during methylation and expressed as a weight percentage of total fatty acids.

\section{IMMUNOFLUORESCENCE IMAGE ANALYSIS}

Longissimus and semitendinosus samples were immersed in optimal cutting temperature solution, frozen in liquid nitrogen, and stored at $-80^{\circ} \mathrm{C}$. Muscle samples were cryosectioned and fiber typed using antibodies for myosin heavy chain (MHC)fast (AbCam, My-32) and MHC-slow (Hybridoma Bank, BA-F8). The number and cross-sectional area of primary and secondary myofibers were counted on 10 different sections for each lamb, and a ratio of secondary to primary myofibers is reported. The cross-sectional area was measured using IMT iSolution Lite (version 9.4, IMT i-Solutions Inc., Vancouver, BC, Canada).

\section{STATISTICAL ANALYSES}

Prolactin data were analyzed in a completely randomized design using MIXED procedure of SAS (SAS Inst. Inc., Cary, NC) with treatment, time, and two-way interaction in the model. Gestation length data was also measured using the MIXED procedure with treatment in the model. Ewe was the experimental unit for both analyses. For all lamb data, data were analyzed in a completely randomized design using MIXED procedure with treatment in the model and lamb as experimental unit. Least square means were generated and separated using the PDIFF option of SAS. Significance was determined at $(P<0.05)$.

\section{RESULTS AND DISCUSSION}

The interaction between day and treatment was significant $(P<$ 0.001 ) for serum PRL levels (Figure 1). On d 30 of gestation ( $5 \mathrm{~d}$ prior to the initiation of dietary treatments), serum PRL levels did not differ between $\mathrm{E}+$ and $\mathrm{E}-$ ewes. At d 50, serum PRL levels in E+ ewes decreased $(P<0.01)$ from pre-treatment levels $(\mathrm{d} 30)$ and were lower $(P<0.01)$ than $\mathrm{E}-$ levels. In $\mathrm{E}-$ ewes, serum PRL levels at d 50 were similar to the values at pre-treatment $(\mathrm{d} 30)$ and higher $(P<0.01)$ than E+ ewe values. At d 130, serum PRL levels increased $(P<0.05)$ in both $\mathrm{E}+$ and $\mathrm{E}-$ ewes compared to $\mathrm{d}$ 50 levels; however, PRL levels were higher $(P<0.01)$ for $\mathrm{E}-$ than $\mathrm{E}+$. The reduction in serum PRL concentration with exposure to 


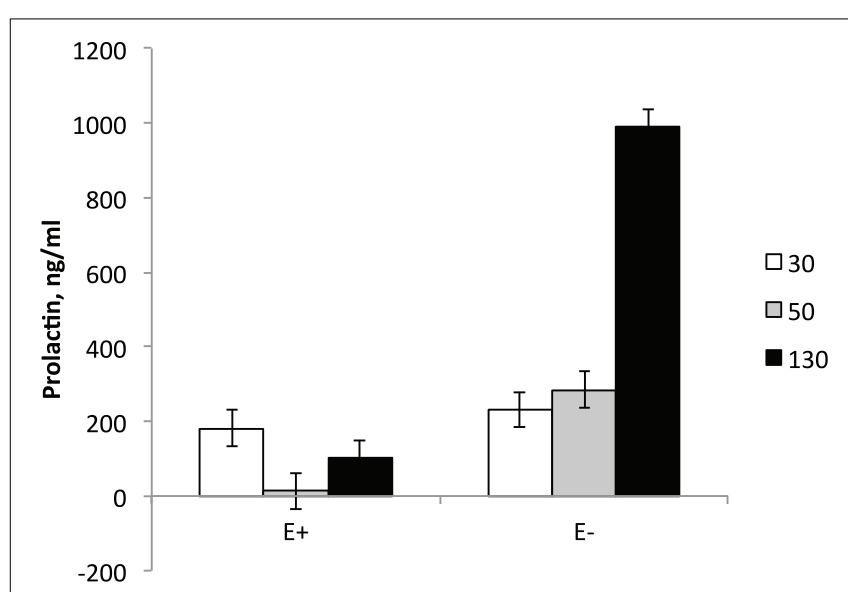

FIGURE 1 | Serum prolactin levels in ewes at d 30, 50, and 130 of gestation. Feeding of tall fescue seed was initiated on d 35 and continued through parturition. Treatment $\times$ time interaction was significant $(P<0.0001)$

ergot alkaloids via grazing endophyte-infected tall fescue pastures or consumption of endophyte-infected tall fescue seed is a classical response observed in sheep (Elsasser and Bolt, 1987; Emile et al., 2000; Parish et al., 2003), cattle (Emile et al., 2000; Watson et al., 2004; Koontz et al., 2012; Stowe et al., 2013), and horses (McCann et al., 1992). It has been documented in multiple species that as parturition approaches maternal serum PRL concentration increases (Chamley et al., 1973; Bryant and Chamley, 1976; Forsyth, 1986) and this increase is hypothesized to be important for maternal lipid metabolism, mammary growth, and milk production and secretion (Hooley et al., 1978; Banchero et al., 2006; Mabjeesh et al., 2013). The levels of PRL reported here for the E- group are consistent with previous reports; however, the drastically lower levels observed at d 130 for E+ could indicate post-partum issues with ewe metabolism and mammary growth, which would negatively impact postnatal lamb growth.

E+ ewes had approximately $4 \mathrm{~d}$ shorter $(P<0.05)$ gestation length than E- controls (Figure 2). Similarly, others have reported shorter gestation lengths in ewes with placental insufficiency (Chen et al., 2010) and cows that were nutrient restricted from d 32-83 of gestation (Long et al., 2010). In contrast, horses grazing endophyte-infected tall fescue during gestation have increased gestation lengths (Putnam et al., 1991). Lamb birth weight was reduced $(P<0.01)$ by $37 \%$ for $\mathrm{E}+$ compared to $\mathrm{E}-$ lambs (Figure 3). Watson et al. (2004) observed a 15\% reduction in calf birth weight from cows grazing toxic vs. non-toxic fescue during gestation. These reductions in fetal growth with ergot alkaloid feeding are similar to those reported for high ambient temperature exposure throughout pregnancy, which produces the most severe intrauterine growth restriction (IUGR; Bell et al., 1987, 1989; Thureen et al., 1992; Anthony et al., 2003; Arroyo et al., 2006). In sheep, umbilical blood flow increases throughout pregnancy in order to keep pace with fetal growth during the last half of gestation (Reynolds et al., 1986; Reynolds and Ferrell, 1987; Molina et al., 1991). Fetal growth restriction is highly correlated with reduced uteroplacental growth and development (Reynolds
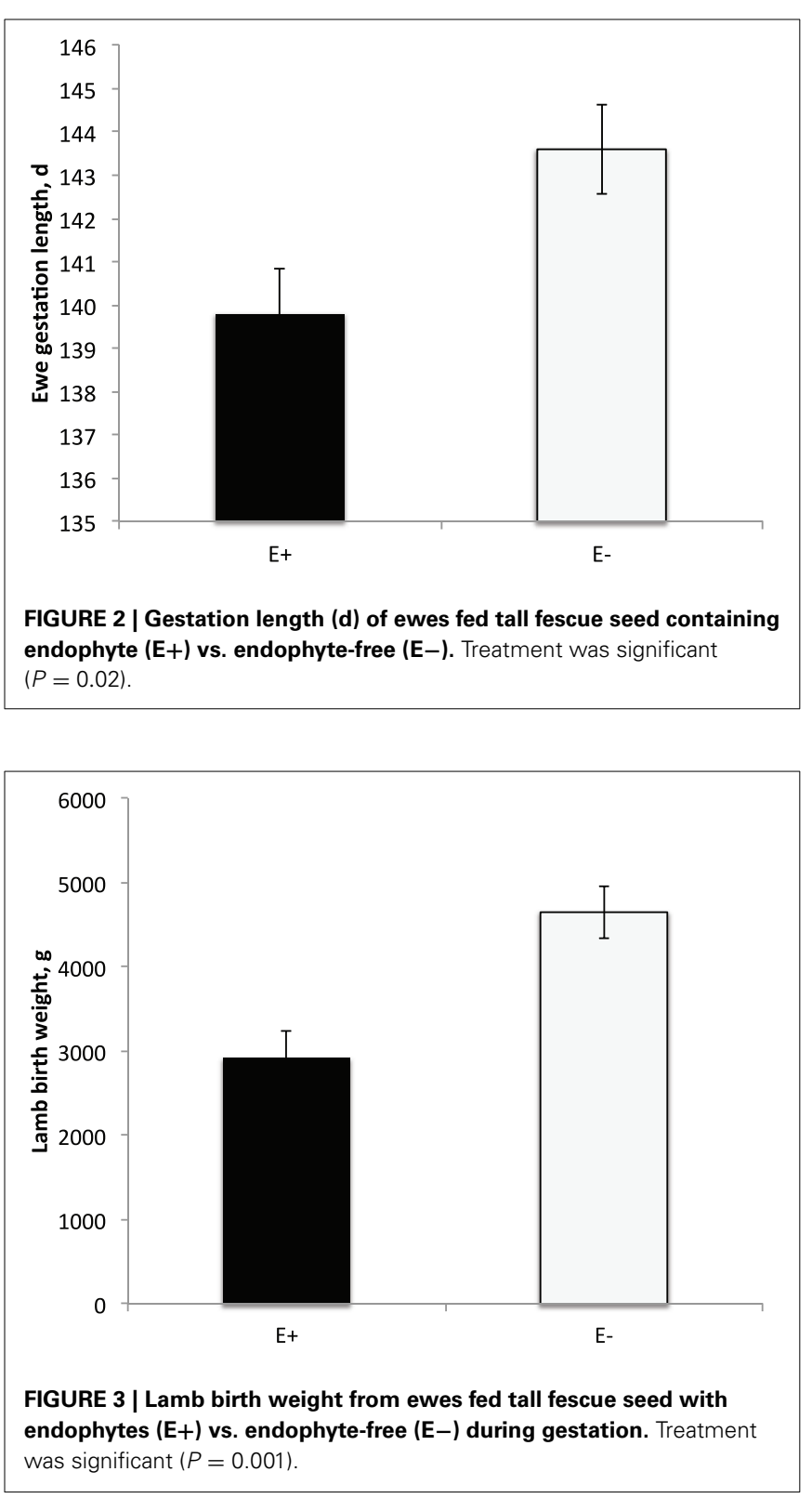

and Redmer, 1995, 2001). Experimental conditions like overnutrition, nutrient restriction, hyperthermia, or high altitude that retard fetal growth also reduce uterine and umbilical blood flows (Reynolds et al., 2006). Because adequate blood flow is essential for normal fetal growth, conditions that restrict fetal and placental growth are associated with reduced rates of placental blood flow and nutrient uptakes by the fetus (Reynolds and Redmer, 1995). Since ergot alkaloids cause vasoconstriction in uterine and umbilical blood flow (Dyer, 1993), these effects would induce fetal growth restriction similar to maternal hyperthermia or nutrient deprivation.

Organ weights (heart, lung, kidneys, spleen, thymus, liver, and pancreas) were also smaller $(P<0.05)$ for $\mathrm{E}+$ than $\mathrm{E}-$ (Table 2$)$ except for the pancreas $(P=0.52)$. Total muscle weight from the right side of each carcass was lighter $(P=0.0093)$ for $E+$ than 
Table 2 | Effect of feeding tall fescue seed with endophyte $(E+)$ vs. endophyte-free ( $E-$ ) to ewes during gestation (d 35 to parturition) on lamb organ, muscle and adipose tissue weights.

\begin{tabular}{lrrcl}
\hline & E+ & E- & SEM & P-Level \\
\hline$n$ & 8 & 8 & & \\
ORGANS, g & & & & \\
Heart & 22.3 & 35.1 & 2.58 & 0.0035 \\
Lungs & 65.4 & 112.3 & 8.76 & 0.0019 \\
Kidneys & 16.7 & 24.0 & 1.64 & 0.0067 \\
Spleen & 4.7 & 9.2 & 1.03 & 0.0081 \\
Thymus & 4.9 & 11.2 & 2.00 & 0.04 \\
Liver & 71.6 & 112.5 & 10.2 & 0.017 \\
Pancreas & 0.84 & 1.3 & 0.050 & 0.52 \\
\hline Total viscera & 234.4 & 311.0 & 29.0 & 0.082 \\
MUSCLES, g & & & & \\
Longissimus & 37.4 & 63.2 & 5.06 & 0.0029 \\
Gluteus medius & 11.5 & 17.6 & 1.73 & 0.02 \\
Semitendinosus & 8.5 & 13.6 & 1.64 & 0.04 \\
Semimembranosus & 24.3 & 43.4 & 4.32 & 0.007 \\
Quadriceps femoris & 24.9 & 41.8 & 3.42 & 0.007 \\
Biceps femoris & 17.2 & 29.7 & 3.30 & 0.02 \\
\hline Total muscle & 313.5 & 510.7 & 46.27 & 0.0093 \\
ADIPOSE, g & & & & \\
Mesenteric fat & 4.6 & 5.2 & 0.58 & 0.51 \\
Kidney fat & 12.5 & 19.8 & 2.28 & 0.04 \\
& & & & \\
\hline & & & & \\
\hline
\end{tabular}

Table 3 | Effect of feeding tall fescue seed with endophyte $(E+)$ vs. endophyte-free ( $E-$ ) to ewes during gestation (d 35 to parturition) on lamb organ, muscle and adipose tissue weights as a percentage of body weight.

\begin{tabular}{lllll}
\hline & E+ & E- & SEM & P-Level \\
\hline$n$ & 8 & 8 & & \\
ORGANS, \% & & & & \\
Heart & 0.76 & 0.76 & 0.04 & 0.96 \\
Lungs & 2.2 & 2.4 & 0.15 & 0.42 \\
Kidneys & 0.57 & 0.52 & 0.03 & 0.32 \\
Spleen & 0.15 & 0.19 & 0.02 & 0.07 \\
Thymus & 0.14 & 0.23 & 0.04 & 0.10 \\
Liver & 2.3 & 2.4 & 0.10 & 0.40 \\
Pancreas & 0.24 & 0.027 & 0.009 & 0.81 \\
\hline Total viscera & 8.0 & 6.7 & 0.45 & 0.06 \\
MUSCLES, \% & & & & \\
Longissimus & 2.6 & 2.7 & 0.13 & 0.57 \\
Gluteus medius & 0.78 & 0.75 & 0.04 & 0.64 \\
Semitendinosus & 0.59 & 0.57 & 0.07 & 0.89 \\
Semimembranosus & 1.6 & 1.8 & 0.14 & 0.28 \\
Quadriceps femoris & 1.7 & 1.8 & 0.06 & 0.23 \\
Biceps femoris & 1.1 & 1.2 & 0.11 & 0.48 \\
\hline Total muscle & 21.2 & 21.7 & 0.95 & 0.72 \\
ADIPOSE, \% & & & & \\
Mesenteric fat & 0.14 & 0.11 & 0.01 & 0.08 \\
Kidney fat & 0.42 & 0.42 & 0.05 & 0.98 \\
& & & &
\end{tabular}

Table 4 | Proximate composition of total muscle mass from one side of each lamb carcass from ewes fed tall fescue seed with endophyte $(E+)$ vs. endophyte-free ( $E-$ ) during gestation (d 35 to parturition).

\begin{tabular}{lrrrr}
\hline & E+ & E- & SEM & P-Level \\
\hline Moisture, \% & 79.05 & 78.64 & 0.09 & 0.01 \\
Crude protein, \% & 17.09 & 18.74 & 0.69 & 0.05 \\
Total Lipid, \% & 2.44 & 2.50 & 0.20 & 0.83 \\
Ash, \% & 2.12 & 2.17 & 0.77 & 0.78 \\
FATTY ACIDS, \% & & & & \\
C14:0 & 0.90 & 1.01 & 0.07 & 0.28 \\
C16:0 & 19.67 & 20.81 & 0.84 & 0.35 \\
C16:1 cis-9 & 2.14 & 2.03 & 0.14 & 0.59 \\
C17:0 & 0.36 & 0.39 & 0.03 & 0.33 \\
C18:0 & 13.13 & 14.44 & 0.52 & 0.10 \\
C18:1 cis-9 & 49.95 & 49.54 & 0.72 & 0.69 \\
C18:1 cis-11 & 3.03 & 2.99 & 0.12 & 0.83 \\
C18:2 cis-9,12 & 0.65 & 0.51 & 0.09 & 0.26 \\
C18:3 cis-9,12,15 & 0.28 & 0.26 & 0.05 & 0.77 \\
C20:4 cis-5,8,11,14 & 1.89 & 0.61 & 0.32 & 0.01 \\
C20:5 cis-5,8,11,14,17 & 0.40 & 0.18 & 0.07 & 0.04 \\
C22:5 cis-7,10,13,16,19 & 0.31 & 0.50 & 0.16 & 0.42 \\
C22:6 cis-4,7,10,13,16,19 & 0.26 & 0.20 & 0.05 & 0.44 \\
Saturated & 33.70 & 36.26 & 1.17 & 0.14 \\
Monounsaturated & 52.09 & 51.57 & 0.77 & 0.64 \\
Polyunsaturated, $n-6$ & 2.54 & 1.12 & 0.37 & 0.02 \\
Polyunsaturated, $n-3$ & 1.25 & 1.16 & 0.22 & 0.76 \\
Ratio of $n-6: n-3$ & 1.96 & 1.07 & 0.20 & 0.01 \\
\hline Total fatty acids, g/100g LT & 1.76 & 1.81 & 0.19 & 0.85 \\
\hline & & & & \\
\hline
\end{tabular}

E-. Individual muscle weights for LT, semitendinosus, semimembranosus, biceps femoris, quadriceps femoris, and gluteus medius were heavier $(P<0.05)$ for $\mathrm{E}-$ than $\mathrm{E}+$. Kidney fat amounts were lower $(P<0.05)$ for $\mathrm{E}+$ than $\mathrm{E}-$. Thymus and spleen mass tended $(P<0.10)$ to be smaller for $\mathrm{E}+$ than $\mathrm{E}-$ even when adjusted for body or carcass weight. All other organs and muscle weights did not differ $(P>0.05)$ when expressed on a weight basis (Table 3). Total viscera weight (weight of the esophagus, rumen, intestines excluding organs) tended to be greater $(P<$ $0.10)$ for $\mathrm{E}+$ than $\mathrm{E}$ - when expressed on a body weight or hot carcass weight basis.

The proximate and fatty acid composition of the total muscle mass from the right side of each lamb carcass is shown in Table 4. Moisture content was higher $(P<0.01)$ and crude protein content was lower $(P=0.05)$ in total muscle from $\mathrm{E}+$ than $\mathrm{E}-$. Total lipid and ash content of the muscle did not differ between treatments. Stearic (C18:0) acid concentrations of the total muscle tended to be lower $(P=0.10)$ for $\mathrm{E}+$ than $\mathrm{E}-$. Arachidonic (C20:4) and eicosapentaenoic (C20:5) acid concentrations were higher $(P<0.05)$ in total muscle of $\mathrm{E}+$ than $\mathrm{E}-$. Other fatty acid concentrations were not altered by dietary treatment. Total $n-6$ polyunsaturated fatty acid (PUFA) and the ratio of $n-6$ to $n-3$ PUFA were higher $(P<0.05)$ in the muscle of $\mathrm{E}+$ than $\mathrm{E}-$. Total fatty acid content of the muscle did not differ, which indicates that PUFA fatty acid accumulation in muscle was greater with 


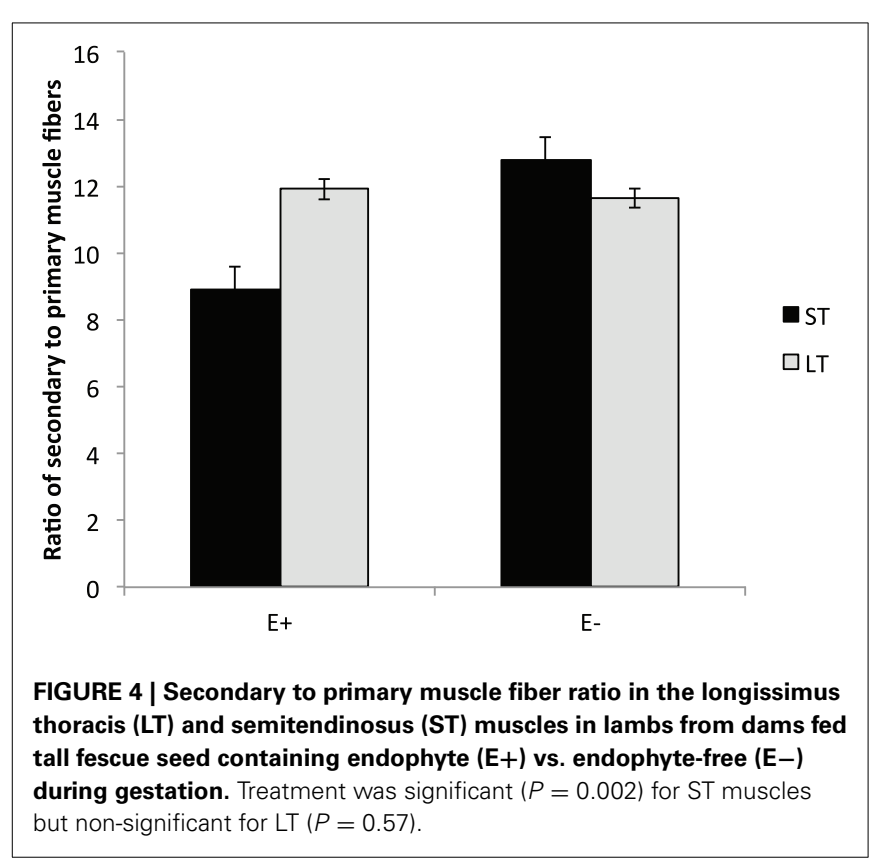

E+ exposure. Realini et al. (2005) reported that finishing steers on endophyte-infected vs. endophyte-free tall fescue increased stearic acid and lowered monounsaturated fatty acid concentrations with no change in PUFA. Ailhaud et al. (2008) found that increased levels of $n-6$ PUFA and a high ratio of $n-6$ to $n$-3 PUFA during fetal development in rats stimulated adipogenesis to alter hypertrophy and hyperplasia of adipocytes during postnatal growth. These alterations in fatty acid composition at birth could impact adipogenesis and subsequent adipose tissue deposition.

Lambs exposed to ergot alkaloids in utero had a lower $(P<$ $0.05)$ secondary to primary muscle fiber ratio in the semitendinosus muscle compared to E- (Figure 4). The ratio of secondary to primary muscle fiber did not differ in the LT. Early prenatal muscle fiber growth is due to hyperplasia of muscle fibers and fiber number is set before birth. Research indicates that muscle fiber hyperplasia is complete by about $70 \mathrm{~d}$ of gestation in the pig (Swatland, 1973), 180 d in the cow (Albrecht et al., 2013), and $105 \mathrm{~d}$ in the sheep (Du et al., 2010). Intrauterine growth restriction of the fetus during the second trimester of gestation reduces the formation of secondary muscle fibers. The ratio of secondary to primary muscle fibers is reduced with intrauterine crowding in pigs (i.e., runt pig, Aberle, 1984; Pardo et al., 2013) and maternal under-nutrition from d 28 to 78 in sheep (Zhu et al., 2004). Cross-sectional area was also reduced $(P<0.05)$ in slow and fast-MHC myofibers of the LT and ST muscles in $\mathrm{E}+$ compared to $\mathrm{E}-$ (Figure 5). Because postnatal muscle growth is predominately through hypertrophy of existing muscle fibers, a reduction in secondary fiber number also impacts postnatal muscle growth. Pigs that are runts at birth have less total carcass muscle mass and altered adipose tissue cellularity when finished to slaughter weights (Powell and Aberle, 1981). Underwood et al. (2010) found that mid to late nutrient restriction of gestating cows altered growth, adipose, and

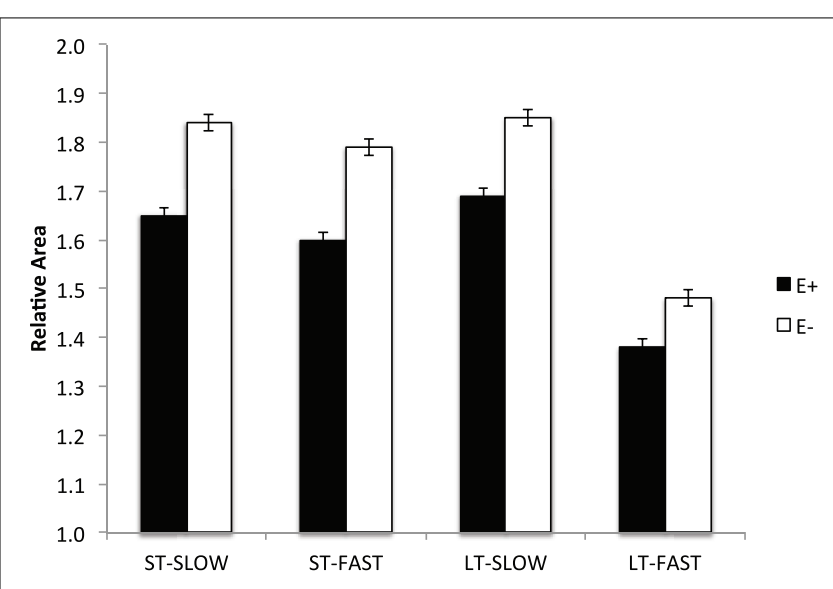

FIGURE 5 | Cross sectional area of muscle fibers (slow- and fast-MHC) in the longissimus thoracis (LT) and semitendinosus (ST) muscles in lambs from dams fed tall fescue seed containing endophyte $(E+)$ vs. endophyte-free (E-) during gestation. Treatment was significant $(P<0.001)$ for both LT and ST muscles.

meat tenderness in the offspring. Long et al. (2012) also reported changes in adipocyte size and carcass parameters in beef offspring from cows with early to mid-gestation undernutrition. Thus, ingestion of ergot alkaloids by ewes during critical time periods of gestation alters fetal muscle growth and development that may have lasting impact on postnatal muscle growth, carcass composition, and palatability throughout the offspring's lifetime.

These results show that fetal growth is restricted in ewes fed endophyte-infected tall fescue seed to simulate fescue toxicosis syndrome during gestation (d 35 to parturition). This reduction in lamb birth weight with ergot alkaloid exposure is similar to lambs exposed in utero to high ambient temperatures, which is the most severe IUGR. Exposure in utero to ergot alkaloids altered skeletal muscle formation by reducing the ratio of secondary to primary myofibers, myofiber hypertrophy in utero, and protein content of muscles. Due to the number of ruminant animals that graze endophyte-infected tall fescue during gestation, additional research is needed to determine mechanisms by which ergot alkaloids reduce fetal growth and the critical time periods of exposure in order to mitigate its effects on fetal growth.

\section{ACKNOWLEDGMENTS}

This research project was supported in part by USDA-NIFA-201038942-20745. Appreciation is expressed to M. C. Miller and T. A. Burns for assistance with animal care and sample collection, and N. Korn for myofiber image acquisition. Technical contribution no. 6263 of the Clemson University Experiment Station.

\section{REFERENCES}

Aberle, E. D. (1984). Myofiber development in skeletal muscles of newborn runt and normal weight. J. Anim. Sci. 59, 1651-1656.

Aiken, G. E., Strickland, J. R., Looper, M. L., Bush, L. P., and Schrick, F. N. (2009). Hemodynamics are altered in the caudal artery of beef heifers fed different ergot alkaloid concentrations. J. Anim. Sci. 87, 2142-2150. doi: 10.2527/jas. 2008-1562 
Ailhaud, G., Guesnet, P., and Cunnane, S. C. (2008). An emerging risk factor for obesity: does disequilibrium of polyunsaturated fatty acid metabolism contribute to excessive adipose tissue development? Brit. J. Nutr. 100, 461-470. doi: $10.1017 /$ S0007114508911569

Albrecht, E., Lembcke, C., Wegner, J., and Maak, S. (2013). Prenatal muscle fiber development and bundle structure in beef and dairy cattle. J. Anim. Sci. 91, 3666-3673. doi: 10.2527/jas.2013-6258

Anthony, R. V., Scheaffer, A. N., Wright, C. D., and Regnault, T. R. H. (2003). Ruminant models of prenatal growth restriction. Reprod. Suppl. 61, 183-194.

Arroyo, J. A., Anthony, R. V., Parker, T. A., and Galan, H. L. (2006). Differential expression of placental and vascular endothelial nitric oxide synthase in an ovine model of fetal growth restriction. Am. J. Obest. Gynecol. 195, 771-777. doi: 10.1016/j.ajog.2006.06.018

Banchero, G. E., Perez Clariget, R., Bencini, R., Lindsay, D. R., Milton, J. T. B., and Martin, G. B. (2006). Endocrine and metabolic factors involved in the effect of nutrition on the production of colostrum in female sheep. Reprod. Nutr. Dev. 46, 447-460. doi: 10.1051/rnd:2006024

Bell, A. W., McBride, B. W., Slepetis, R., Early, R. J., and Currie, W. B. (1989). Chronic heat stress and prenatal development in sheep: I. Conceptus growth and maternal plasma hormones and metabolites. J. Anim. Sci. 67, 3289-3299.

Bell, A. W., Wilkening, R. B., and Meschia, G. (1987). Some aspects of placental function in chronically heat-stressed ewes. J. Dev. Physiol. 9, 17-29.

Berde, B. (1980). "Ergot compounds: a synopsis," in Ergot Compounds and Brain Function: Nueroendocrine and Neuropsychiatric Aspects, eds M. Goldstein, A. Lieberman, D. B. Calne, and M. O. Thorner (New York, NY: Raven Press), 4-23.

Bernard, J. K., Chestnut, A. B., Erickson, B. H., and Kelly, F. M. (1993). Effects of prepartum consumption of endophyte-infected tall fescue on serum prolactin and subsequent milk production of Holstein cows. J. Dairy Sci. 76, 1928-1933. doi: 10.3168/jds.S0022-0302(93)77526-8

Bryant, G. D., and Chamley, W. A. (1976). Plasma relaxin and prolactin immunoactivities in pregnancy and at parturition in the ewe. J. Reprod. Fert. 48, 201-204. doi: 10.1530/jrf.0.0480201

Chamley, W. A., Buckmaster, J. M., Cerini, M. E., Cumming, I. A., Goding, J. R., Obst, J. M., et al. (1973). Changes in the levels of progesterone, corticosteroids, estrone, estradiol-17 $\beta$, luteinizing hormone and prolactin tin the peripheral plasma of the ewe during late pregnancy and at parturition. Biol. Reprod. 9, 30-35.

Chen, X., Fahy, A. L., Green, A. S., Anderson, M. J., Rhoades, R. P., and Limesand, S. W. (2010). $\beta 2$-Adrenergic receptor desensitization in perirenal adipose tissue in fetuses and lambs with placental insufficiency-induced intrauterine growth restriction. J. Physiol. 588 (Pt 18), 3539-3549. doi: 10.1113/jphysiol.2010.192310

Du, M., Tong, J., Zhao, J., Underwood, K. R., Zhu, M., Ford, S. P., et al. (2010). Fetal programming of skeletal muscle development in the ruminant animals. J. Anim. Sci. 88, E51-E60. doi: 10.2527/jas.2009-2311

Dyer, D. C. (1993). Evidence that ergovaline acts on serotonin receptors. Life Sci. 53, PL223-PL228. doi: 10.1016/0024-3205(93)90555-H

Elsasser, T. H., and Bolt, D. J. (1987). Dopaminergic-like activity in toxic fescue alters prolactin but not growth hormone or thyroid stimulating hormone in ewes. Domest. Anim. Endocrinol. 4, 259-269. doi: 10.1016/0739-7240(87) 90022-1

Emile, J. C., Bony, S., and Ghesquiere, M. (2000). Influence of consumption of endophyte-infested tall fescue hay of heifers and lambs. J. Anim. Sci. 78, 358-364.

Forsyth, I. A. (1986). Variation among species in the endocrine control of mammary growth and function: the roles of prolactin, growth hormone, and placental lactogen. J. Dairy Sci. 69, 886-903. doi: 10.3168/jds.S0022-0302(86)80479-9

Hooley, R. D., Campbell, J. J., and Findlay, J. K. (1978). The importance of prolactin for lactation in the ewe. J. Endocrinol. 79, 301-310. doi: 10.1677/joe.0.0790301

Hoveland, C. S. (1993). Importance and economic significance of the Acremonium endophytes on performance of animals and grass plants. Agr. Ecosyst. Environ. 44, 3-12. doi: 10.1016/0167-8809(93)90036-O

Klotz, J. L., Brown, K. R., Xue, Y., Matthews, J. C., Boling, K. A., Bush, L. P., et al. (2012). Alterations in serotonin receptor-induced contractility of bovine lateral saphenous vein in cattle grazing endophyte-infected tall fescue. J. Anim. Sci. 90, 682-693. doi: 10.2527/jas.2011-4323

Klotz, J. L., Bush, L. P., Smith, D. L., Shafer, W. D., Smith, L. L., Vevoda, A. C., et al. (2006). Assessment of vasoconstrictive potential of D-lysergic acid using an isolated bovine lateral saphenous vein bioassay. J. Anim. Sci. 84, 3167-3175. doi: $10.2527 /$ jas.2006-038
Koontz, A. F., Bush, L. P., Klotz, J. L., McLeod, K. R., Schrick, F. N., and Harmon, D. L. (2012). Evaluation of a ruminally dosed tall fescue seed extract as a model for fescue toxicosis in steers. J. Anim. Sci. 90, 914-921. doi: 10.2527/jas.2011-4292

Long, N. M., Prado-Cooper, M. J., Krehbiel, C. R., DeSilva, U., and Wettemann, R. P. (2010). Effects of nutrient restriction of bovine dams during early gestation on postnatal growth, carcass, and organ characteristics, and gene expression in adipose tissue and muscle. J. Anim. Sci. 88, 3251-3261. doi: 10.2527/jas.20092512

Long, N. M., Tousley, C. B., Underwood, K. R., Paisley, S. I., Means, W. J., Hess, B. W., et al. (2012). Effects of early- to mid-gestational undernutrition with or without protein supplementation on offspring growth, carcass characteristics, and adipocyte size in beef cattle. J. Anim. Sci. 90, 197-206. doi: 10.2527/jas. 2011-4237

Mabjeesh, S. J., Sabastian, C., Gal-Garber, O., and Shamay, A. (2013). Effect of photoperiod and heat stress in the third trimester of gestation on milk production and circulating hormones in dairy goats. J. Dairy Sci. 96, 189-197. doi: 10.3168/jds.2012-5624

McCann, J. S., Caudle, A. B., Thompson, F. N., Stuedemann, J. A., Heusner, G. L., and Thompson, D. L. Jr. (1992). Influence of endophyte-infected tall fescue on serum prolactin and progesterone in gravid mares. J. Anim. Sci. 70, 217-223.

Molina, R. D., Meschia, G., Battaglia, F. C., and Hay, W. W. Jr. (1991). Gestational maturation of placental glucose transfer capacity in sheep. Am. J. Physiol. 261, R697-R704.

Pardo, C. E., Berard, J., Kreuzer, M., and Bee, G. (2013). Intrauterine crowding impairs formation and growth of secondary myofibers in pigs. Animal 7, 430-438. doi: 10.1017/S1751731112001802

Parish, J. A., McCann, M. A., Watson, R. H., Hoveland, C. S., Hawkins, L. L., Hill, N. S., et al. (2003). Use of nonergot alkaloid-producing endophytes for alleviating tall fescue toxicosis in sheep. J. Anim. Sci. 81, 1316-1322.

Park, P. W., and Goins, R. E. (1994). In situ preparation of fatty acid methyl esters for analysis of fatty acid composition in foods. J. Food Sci. 59, 1262-1266. doi: 10.1111/j.1365-2621.1994.tb14691.x

Peters, C. W., Grigsby, K. N., Aldrich, C. G., Paterson, J. A., Lipsey, R. J., Kerley, M. S., et al. (1992). Performance, forage utilization, and ergovaline consumption by beef cows grazing endophyte fungus-infected tall fescue, endophyte fungus-free tall fescue, and orchardgrass pastures. J. Anim. Sci. 70, 1550-1561.

Powell, S. E., and Aberle, E. D. (1981). Skeletal muscle and adipose tissue cellularity in runt and normal birth weight swine. J. Anim. Sci. 52, 748-756.

Putnam, M. R., Brandby, D. I., Schumacher, J., Boosinger, T. R., Bush, L., Shelby, R. A., et al. (1991). Effects of the fungal endophyte Acremonium coenophialum in fescue on pregnant mares and foal viability. J. Anim. Sci. 52, 2071-2074.

Realini, C. E., Duckett, S. K., Hill, N. S., Hoveland, C. S., Lyon, B. G., Sackmann, J. R., et al. (2005). Effect of endophyte type on carcass traits, meat quality, and fatty acid composition of beef cattle grazing tall fescue. J. Anim. Sci. 83, 430-439.

Reynolds, L. P., Caton, J. S., Redmer, D. A., Grazul-Bilska, A. T., Vonnahme, K. A., Borowicz, P. P., et al. (2006). Evidence for altered placental blood flow and vascularity in compromised pregnancies. J. Physiol. 572, 51-58. doi: 10.1113/jphysiol.2005.104430

Reynolds, L. P., and Ferrell, C. L. (1987). Transplacental clearance and blood flows of bovine gravid uterus at several stages of gestation. Am. J. Physiol. 253, R753-R759.

Reynolds, L. P., Ferrell, C. L., Robertson, D. A., and Ford, S. P. (1986). Metabolism of the gravid uterus, foetus, and uteroplacenta at several stages of gestation in cows. J. Agric. Sci. (Camb.) 106, 437-444. doi: 10.1017/S002185960 0063309

Reynolds, L. P., and Redmer, D. A. (1995). Utero-placental vascular development and placental function. J. Anim. Sci. 73, 1839-1851.

Reynolds, L. P., and Redmer, D. A. (2001). Minireview: angiogenesis in the placenta. Biol. Reprod. 64, 1033-1040. doi: 10.1095/biolreprod64.4.1033

Stowe, H. M., Miller, M., Burns, M. G., Calcatera, S. M., Andrae, J. G., Aiken, G. E., et al. (2013). Effects of fescue toxicosis on bull growth, semen characteristics, and breeding soundness evaluation. J. Anim. Sci. 91, 3686-3692. doi: 10.2527/jas.2012-6078

Strickland, J. R., Looper, M. L., Matthews, J. C., Rosenkrans, C. F. Jr., Flythe, M. D., and Brown, K. R. (2011). Board-invited review: St. Anthony's fire in livestock: causes, mechanisms, and potential solutions. J. Anim. Sci. 89, 1603-1626. doi: 10.2527/jas.2010-3478 
Stuedemann, J. A., and Hoveland, C. S. (1988). Fescue endophyte: history and impact on animal agriculture. J. Prod. Agric. 1, 39-44. doi: 10.2134/jpa1988.0039

Swatland, H. J. (1973). Muscle growth in the fetal and neonatal pig. J. Anim. Sci.37, $536-545$.

Thureen, P. J., Trembler, K. A., Meschia, G., Makowski, E. L., and Wilkening, R. B. (1992). Placental glucose transport in heat-induced fetal growth retardation. Am. J. Physiol. 263, R578-R585.

Underwood, K. R., Tong, J. F., Price, P. L., Roberts, A. J., Grings, E. E., Hess, B. W., et al. (2010). Nutrition during mid to late gestation affects growth, adipose tissue deposition, and tenderness in cross-bred beef steers. Meat Sci. 86, 588-593. doi: 10.1016/j.meatsci.2010.04.008

Watson, R. H., McCann, M. A., Parish, J. A., Hoveland, C. S., Thompson, F. N., and Bouton, J. H. (2004). Productivity of cow-calf pairs grazing tall fescue pastures infected with either the wild-type endophyte or a nonergot alkaloid-producing endophyte strain, AR542. J. Anim. Sci. 82, 3388-3393.

Weber, H. P. (1980). "Ergot compounds: a synopsis," in Ergot Compounds and Brain Function: Nueroendocrine and Neuropsychiatric Aspects, eds M. Goldstein, A. Lieberman, D. B. Calne, and M. O. Thorner ( New York, NY: Raven Press), 25-34.
Zhu, M. J., Ford, S. P., Nathanielsz, P. W., and Du, M. (2004). Effect of maternal nutrient restriction in sheep on the development of fetal skeletal muscle. Biol. Reprod. 71, 168-173. doi: 10.1095/biolreprod.104.034561

Conflict of Interest Statement: The authors declare that the research was conducted in the absence of any commercial or financial relationships that could be construed as a potential conflict of interest.

Received: 13 June 2014; accepted: 04 August 2014; published online: 21 August 2014. Citation: Duckett SK, Andrae JG and Pratt SL (2014) Exposure to ergot alkaloids during gestation reduces fetal growth in sheep. Front. Chem. 2:68. doi: 10.3389/fchem. 2014.00068

This article was submitted to Chemical Biology, a section of the journal Frontiers in Chemistry.

Copyright (C) 2014 Duckett, Andrae and Pratt. This is an open-access article distributed under the terms of the Creative Commons Attribution License (CC BY). The use, distribution or reproduction in other forums is permitted, provided the original author(s) or licensor are credited and that the original publication in this journal is cited, in accordance with accepted academic practice. No use, distribution or reproduction is permitted which does not comply with these terms. 